\title{
Managing Organizations in the Creative Industries: Organizational Behavior for the Cultural Sector
}

\author{
Paul Saintilan \\ Collarts and Macleay Colleges \\ David Schreiber \\ Belmont University
}

This paper was presented at the 2018 International Summit of the

Music \& Entertainment Industry Educators Association

March 22-24, 2018

https://doi.org/10.25101/18.37

\section{Abstract}

The increased use of blended and online delivery is resulting in greater integration of video resources in educational materials. The authors recently published a textbook where they were encouraged by the publisher (Routledge) to provide online companion materials. The book features case studies, including a number of short vignettes of creative workplace conflicts. With the financial assistance of a MEIEA grant, the authors commissioned videos of "expert managerial perspectives" as responses to six of these cases. The authors provide concrete examples, show how it is intended to be used in course delivery, and seek feedback on the strengths and weaknesses of this approach to encourage continual improvement.

Keywords: creative industries, creative industries pedagogy, organizational behavior, managing organizations, workplace conflicts
This project was funded by a MEIEA research grant.

Paul Saintilan is CEO of Collarts and Macleay Colleges in Australia. He recently co-authored a textbook with Dr. David Schreiber on Managing Organizations in the Creative Economy: Organizational Behavior for the Cultural Sector through Routledge Publishing in the U.K. He is completing a PhD at Deakin University on "Managerial orientations, thought worlds and underlying beliefs in large music

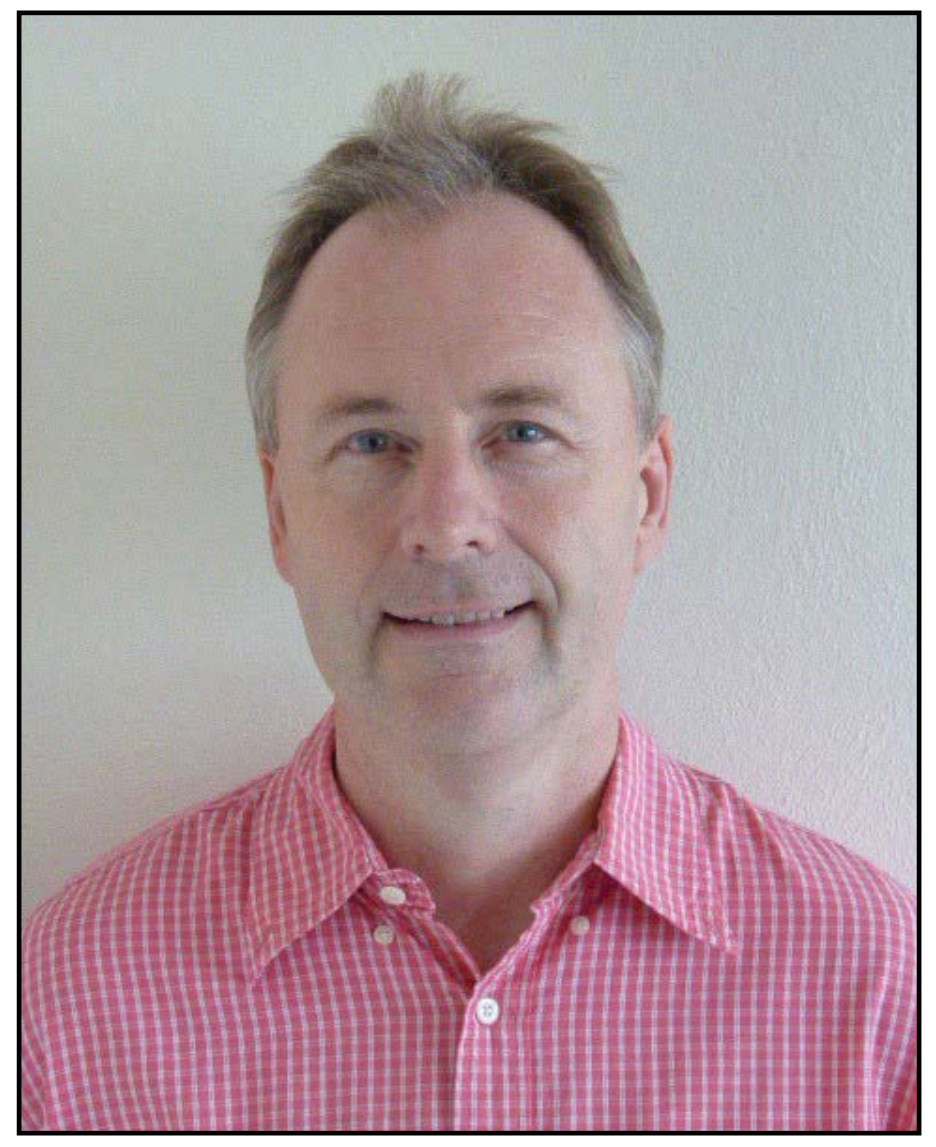


organisations." Before undertaking his CEO role Saintilan served as Dean of Collarts and Head of Arts and Entertainment Management at the Australian Institute of Music. He is a member of The College of Teachers, London, the Editorial Review Board of the MEIEA Journal and the International Music Business Research Association. Prior to his time in academia, Saintilan trained as a music composer, before graduating with an MBA degree and pursuing a career in recorded music. In the 1990s he held international marketing director positions with EMI Music and Universal Music in London.

David Schreiber is an Assistant Professor and Chair of the Entertainment Industry Studies program at Belmont University in Nashville. His research interests include the influences upon strategic decision-making practices within music industry micro-enterprises and the role of strategic sexual performance as it is used in creative and cultural industry organizations. He recently co-authored a textbook with Paul Saintilan on Managing Organizations in the Creative Economy: Organizational Behaviour for the Cultural Sector through Routledge Publishing in the U.K. He is also working on a textbook titled Principles and Practice of the Global Music Business through Kendall Hunt Publishing. Furthermore, Schreiber is a member of the Academy of Management (AOM), European Group of Organization Studies (EGOS), the Music and Entertainment Industry Ed-

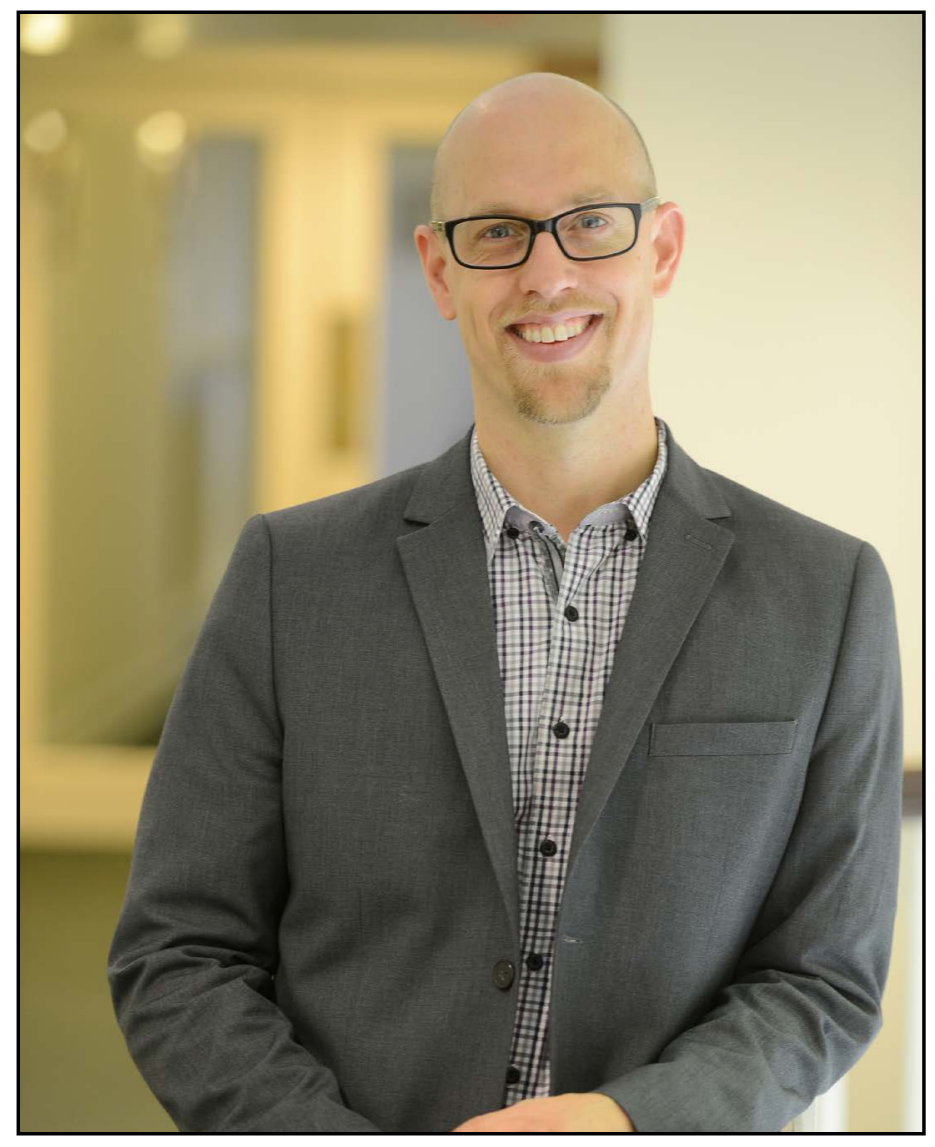

ucators Association; is a reviewer for the Journal of Small Business Management and recently served as an Associate Editor of the MEIEA Journal. Prior to his time in academia, Schreiber began his career as an independent musician and teacher before moving into a Regional Sales Manager position at Schmitt Music. He later took positions as a Marketing and Business Development Manager for Shiny Penny Productions, in the licensing and royalty department of Miami Records, as Business Development Manager at Pivot Entertainment, and managed artist Dean Fields. 


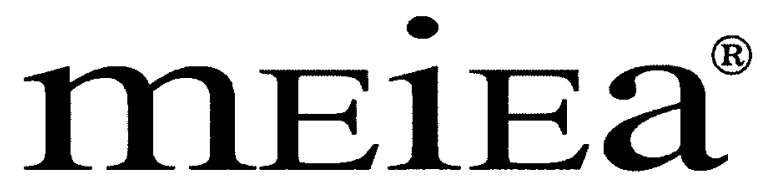

MUSIC \& ENTERTAINMENT INDUSTRY

EDUCATORS ASSOCIATION

\section{PROCEEDINGS OF THE \\ 2018 INTERNATIONAL SUMMIT}

OF THE

\section{MUSIC \& ENTERTAINMENT INDUSTRY EDUCATORS \\ ASSOCIATION}
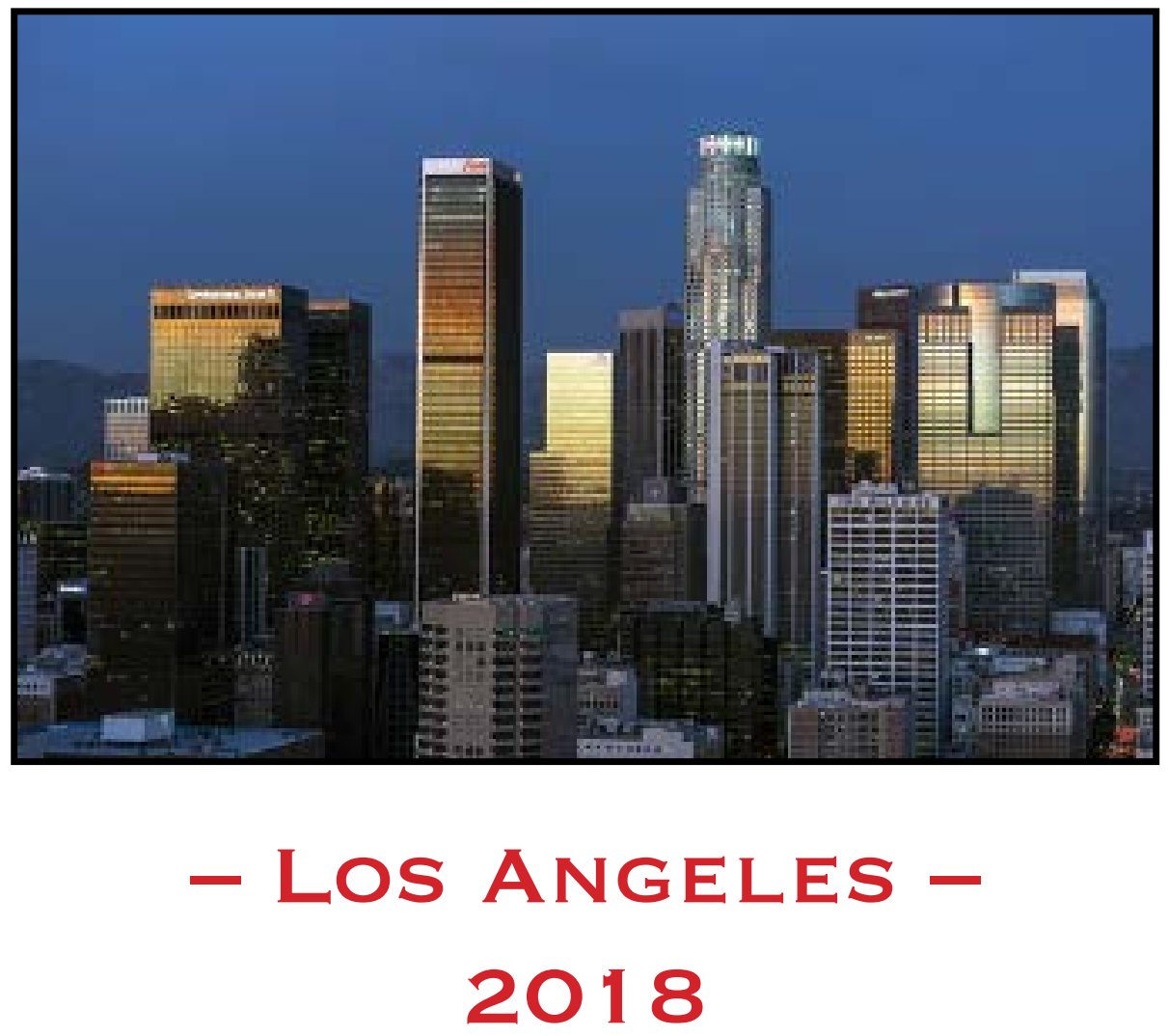

March 22 - 24, $2018 \cdot$ Embassy Suites by Hilton - Los Angeles/Glendale 